\title{
PATH ANALYSIS TERHADAP FAKTOR-FAKTOR YANG MEMPENGARUHI PRESTASI SISWA
}

\author{
Rezzy Eko Caraka1,2, Sugiarto ${ }^{3}$ \\ ${ }^{1}$ School of Mathematical Sciences, Faculty of Science and Technology, The National University of Malaysia, Malaysia \\ 2Bioinformatics and Data Science Research Center, Bina Nusantara University, Jakarta, Indonesia \\ ${ }^{3}$ Kepala Sekolah Menengah Atas Negeri 2 Karimun (SMAN 2) Kabupaten Karimun, Kepulauan Riau, Indonesia \\ rezzyekocaraka@gmail.com
}

\begin{abstract}
Abstrak
Pendidikan merupakan aspek fundamental yang perlu diperhatikan Tujuan utama dari pendidikan adalah peningkatan kualitas sumber daya manusia (SDM) baik secara personal maupun komunal. Pencerminan dari kualitas SDM yang unggul salah satunya diindikasikan dengan pencapaian prestasi seorang individu pada saat menempuh pendidikan mulai dari tingkat dasar hingga tingkat tinggi. Prestasi belajar siswa dipengaruhi oleh faktor yang berasal dari dalam diri dan fakor yang berasal dari luar diri siswa. Faktor yang terdapat dalam diri siswa adalah intelegensi, motivasi, minat, bakat, kondisi fisik, sikap dan kebiasaan siswa. Sedangkan yang termasuk faktor yang berasal dari luar diri siswa adalah keadaan sosial ekonomi, lingkungan, sarana dan prasarana, guru dan cara mengajarnya. Pada penelitian ini digunakan analisis jalur yang merupakan bentuk modifikasi dari analisis regresi dimana variabel bebas yang diteliti tidak hanya mempengaruhi variabel terikat secara langsung, tetapi juga dapat mempengaruhi variabel tersebut secara tidak langsung. Variabel-variabel bebas tersebut memiliki pengaruh langsung dan pengaruh tak langsung terhadap variabel terikat. Berdasarkan hasil pembahasan, diperoleh kesimpulan bahwa untuk meningkatkan nilai rata-rata UN variable uang saku dan lama akses internet menjadi hal yang perlu diperhatikan oleh guru dan juga pihak lainnya yang terlibat pada pendidikan selain itu diketahui dari pengaruh tidak langsung.
\end{abstract}

Kata kunci: prestasi, siswa, analisis jalur, pendidikan

\section{PATH ANALYSIS ON FACTORS INFLUENCING STUDENTS ACHIEVEMENT}

\author{
Rezzy Eko Caraka1,2, Sugiarto ${ }^{3}$ \\ ${ }^{1}$ School of Mathematical Sciences, Faculty of Science and Technology, The National University of Malaysia, Malaysia \\ ${ }^{2}$ Bioinformatics and Data Science Research Center, Bina Nusantara University, Jakarta, Indonesia \\ ${ }^{3}$ Kepala Sekolah Menengah Atas Negeri 2 Karimun (SMAN 2) Kabupaten Karimun, Kepulauan Riau, Indonesia \\ rezzyekocaraka@gmail.com
}

\begin{abstract}
On the one hand, education is a fundamental aspect to pay attention. The main purpose of education is the improvement of the quality of human resources (HR) both personal and communal. The reflection of the superior quality of human resources is indicated by the achievement of individual achievement at the time of education starting from the basic level to high level. Student achievement is influenced by factors that come from within self and that comes from outside. The factors contained within students is the intelligence, motivation, interests, talents, physical conditions, attitudes and habits. Likewise, the factors that come from outside the student is the socio-economic conditions, environment, facilities and infrastructure, teachers and how to teach. Apart from that, In this study, we used path analysis which is a modified form of regression analysis where the independent variables studied not only affect the dependent variable directly but also can affect the variable indirectly. These independent variables have a direct and indirect effect on the dependent variable. Based on the results of the discussion, it can be concluded that to increase the average of the national exam (UN) the variable of allowance and time of internet access become primary factors that need to be considered by teachers and also other parties involved in education other than it is known from indirect influence.
\end{abstract}

Keywords: Achievement, Student, Path Analysis, Education 


\section{Pendahuluan}

Indonesia bersiap untuk meningkatkan kesejahteraan, menghindari diri dari terperangkap di zona negara berpenghasilan menengah, dan bertekad untuk tak meninggalkan siapapun dalam upayanya mengejar negara-negara berpenghasilan tinggi. Semua ini adalah cita-cita yang ambisius. Untuk mewujudkan tekat tersebut maka pendidikan merupakan aspek yang perlu diperhatikan. Tekat tersebut juga tertuang dalam Undang-Undang Nomor 20 Tahun 2003 tentang Sistem Pendidikan Nasional pasal 6 ayat (1) (Depdiknas, 2003) menyebutkan bahwa setiap warga negara yang berusia 7-15 (tujuh sampai dengan lima belas) tahun wajib mengikuti pendidikan dasar. Undang-Undang Nomor 20 Tahun 2003 tentang Sistem Pendidikan Nasional pasal 34 ayat (2) (Depdiknas, 2003) menyebutkan bahwa Pemerintah dan pemerintah daerah menjamin terselenggaranya wajib belajar minimal pada jenjang pendidikan dasar tanpa memungut biaya, sedangkan dalam ayat (3) menyebutkan bahwa wajib belajar merupakan tanggung jawab negara yang diselenggarakan oleh lembaga pendidikan pemerintah, pemerintah daerah, dan masyarakat. Konsekuensi dari amanat undangundang tersebut adalah Pemerintah dan pemerintah daerah wajib memberikan layanan pendidikan bagi seluruh siswa pada tingkat pendidikan dasar (SD dan SMP) serta sekolah lain yang sederajat.

Dana BOS salah satu porgram pemerintah yang dapat digunakan untuk menunjang prestasi siswa di sekolah. Besaran dana BOS yang diterima oleh setiap sekolah akan berbeda-beda sesuai dengan kebutuhan nyata dari sekolah yang dinilai urgen oleh pemerintah. Perbedaan ini bertujuan agar dana dapat digunakan secara maksimal untuk meningkatkan prestasi belajar siswa. Aplikasi penggunaan dana ini secara umum mencakup seluruh aspek yang diperlukan. Aspek yang dimaksud adalah penyelenggaraan pendidikan oleh sekolah hingga keperluan pribadi peserta didik dalam menunjang kelancarannya mengikuti proses belajar di sekolah.
Beberapa penelitian terdahulu tentang dana BOS seperti yang dilakukan oleh Diputra \& Indra (2010) mendapatkan kesimpulan bahwa variabel bantuan operasional sekolah, kemampuan ekonomi orang tua dan rata-rata masa kerja guru baik secara simultan maupun parsial berpengaruh signifikan terhadap prestasi belajar siswa Sekolah Dasar Negeri di Kota Denpasar.

Caraka \& Sugiarto (2017) melakukan pemodelan dana bos terhadap prestasi pelajar dan didapatkan kesimpulan bahwa rata-rata nilai rapot siswa dan siswi memiliki hubungan yang positif apabila dana BOS digunakan untuk penggunaan perpustakaan, pembelajaran dan ekstrakurikuler siswa, dan siswa miskin. Sedangkan hubungan jasa dan penerimaan siswa baru memiliki hubungan yang negative.

Salah satu analisis statistik yang dapat digunakan untuk menganalisis hubungan sebab akibat dan pengaruh langsung maupun tidak langsung dari beberapa variabel adalah analisis jalur (Path Analysis). Pada level pendidikanyang lebih tinggi di Universitas (Hakam, 2015) melakukan analisis prestasi belajar diukur dengan IPK (Indeks Prestasi Kumulatif). Faktor-faktor yang mempengaruhi IPK antara lain uang saku, usia, nilai UN SMA, banyak organisasi, lama internet, lama belajar. Pada penelitian ini peneliti melakukan pengembangan dan diapplikasikan pada tingkat pendidikan sekolah menengah atas dengan mempertimbangkan variabel lama belajar, usia, lama penggunaan internet, rata-rata nlai rapor, rata-rata nilai ujian nasional dan juga banyak ekskul yang diikuti oleh siswa.

\section{Analisis Regresi}

Analisis regresi menurut Bates \& Watts (1988) adalah analisis yang berkenaan dengan studi ketergantungan satu variabel yaitu variabel tidak bebas (dependent variables) pada satu atau lebih variabel lain, variabel yang menjelaskan (independent variables) dengan tujuan menaksir atau meramalkan nilai rata-rata dari variabel tidak bebas apabila nilai variabel yang menerangkan sudah diketahui. Variabel yang 
menerangkan sering disebut variabel bebas (independent variable). Bentuk regresi linier merupakan bentuk regresi yang paling sering digunakan. Menurut model regresi linier dengan satu variabel bebas $X$ dan satu variabel tak bebas $Y$ disebut regresi linier sederhana, dengan bentuk persamaan:

$$
\mathrm{Y}_{\mathrm{i}}=\mathrm{b}_{0}+\mathrm{b}_{1} \mathrm{X}_{\mathrm{i}}+\mathrm{e}_{\mathrm{i}}
$$

dengan $\mathrm{i}=1,2,3, \ldots, \mathrm{n}$

Asumsi-asumsi untuk model regresi linier adalah sebagai berikut (Atkinson, 1986):

1. $E\left(e_{i} \mid X_{i}\right)=0$

Artinya nilai yang diharapkan dari $e_{i}$ tergantung pada $X_{i}$ tertentu adalah nol.

2. $\operatorname{Cov}\left(e_{i}, e_{j}\right)=E\left[e_{i}-E\left(e_{i}\right)\right]\left[e_{i}-E\left(e_{j}\right)\right]$

$$
=E\left(e_{i} e_{j}\right)
$$$$
=0
$$

dengan $i \neq j$

Biasa dikenal dengan sebutan asumsi tidak adanya korelasi berurutan atau tidak ada autokorelasi.

3. $\operatorname{Var}\left(\mathrm{e}_{\mathrm{i}} \mid \mathrm{X}_{\mathrm{i}}\right)=\mathrm{E}\left[\mathrm{e}_{\mathrm{i}}-\mathrm{E}\left(\mathrm{e}_{\mathrm{i}}\right)\right]^{2}$

$$
\begin{aligned}
& =\mathrm{E}\left(\mathrm{e}^{2}\right) \\
& =\mathrm{\sigma}^{2}
\end{aligned}
$$

Menyatakan asumsi homoskesdastisitas atau varian sama. Apabila dalam persamaan regresi tercakup dua variabel atau lebih (termasuk variabel tak bebas Y), maka regresi ini disebut regresi linier berganda (multiple linear regression). Bentuk umum dari persamaan regresi linier berganda dengan variabel tak bebas $\mathrm{Y}$ dan $\mathrm{k}$ variabel $\mathrm{X}_{1}, \mathrm{X}_{2}, \mathrm{X}_{3}, \ldots, \mathrm{X}_{\mathrm{k}}$ adalah:

$Y_{i}=b_{0}+b_{1} X_{1 i}+b_{2} X_{2 i}+b_{2} X_{3 i}+\ldots+b_{k} X_{k i}+e_{i}$

dengan

$$
\begin{array}{ll}
\mathrm{i} & =1,2,3, \ldots, \mathrm{n} \\
\mathrm{b}_{0} & =\text { intersep } \\
\mathrm{b}_{1}, \mathrm{~b}_{2}, \ldots, \mathrm{b}_{\mathrm{k}} & =\text { koefisien regresi } \\
\mathrm{e}_{\mathrm{i}} & =\text { unsur gangguan } \\
\mathrm{i} & =\text { observasi ke } \mathrm{i} \\
\mathrm{n} & =\text { besarnya sampel }
\end{array}
$$

Secara sederhana dapat dikatakan bahwa $e_{i}$ menyatakan selisih antara nilai $Y$ yang sebenarnya dengan nilai taksiran dari regresi. Misalkan variabel dependen dari su-atu model dilambangkan dengan $\mathrm{Y}$, maka:

$$
e_{i}=Y_{i}-\hat{Y}_{i}
$$

Sedangkan untuk model regresi linier 3 variabel atau lebih menggunakan asumsiasumsi sebagai berikut:

1. $\mathrm{E}\left(\varepsilon_{\mathrm{i}}\right)=0$ untuk setiap $\mathrm{i}=1,2, . ., \mathrm{n}$

Artinya, rata-rata kesalahan pengganggu adalah nol.

2. $\operatorname{Kov}\left(\varepsilon_{i}, \varepsilon_{\mathrm{j}}\right)=0$, dengan $\mathrm{i} \neq \mathrm{j}$

Artinya tidak terdapat korelasi antara kesalahan pengganggu.

3. $\operatorname{Var}\left(\varepsilon_{\mathrm{i}}\right)=\sigma^{2}$

Artinya setiap kesalahan pengganggu memiliki varian yang sama (asumsi homoskedastisitas)

4. Tidak terdapat kolinieritas ganda (multikolinieritas) diantara variabel bebas X.

Asumsi heteroskedastisitas dapat diuji dengan menggunakan uji Glejser (Glejser Test) (Furno, 2005). Nilai kesalahan penganggu atau residual dari regresi diberi harga mutlak. Untuk pembuktian tidak adanya multikolinieritas dapat menggunakan nilai VIF (Variance Inflacion Factor). Jika nilai VIF lebih besar dari 10, maka dapat diindikasikan terjadi gejala multikolinieritas Untuk Asumsi Autokorelasi dapat diketahui dengan uji d Durbin-Watson yang kemudian nilai dw dibandingkan dengan nilai dU dan $\mathrm{dL}$ yang terdapat pada tabel Durbin Watson. Asumsi normalitas diuji dengan menggunakan uji Kolmogorov Smirnov (Conover, 1971).

Analisis Jalur (path analysis)

Land (1969) menjelaskan bahwa Path Analysis ialah suatu teknik untuk menganalisis hubungan sebab akibat yang terjadi pada regresi berganda jika variabel bebasnya mempengaruhi variabel tergantung tidak hanya secara langsung tetapi juga secara tidak langsung. Regresi dikenakan pada masing-masing variabel dalam suatu 
model sebagai variabel tergantung (pemberi respon) sedang yang lain sebagai penyebab. Analisis Jalur (Path Analysis) biasa digunakan dalam ilmu sosial, ekonomi, dan ilmu-ilmu yang mempelajari tentang perilaku manusia. Seperti halnya analisis regresi, analisis jalur juga digunakan untuk melihat dan menentukan variabel apa saja atau jalur mana saja yang dihipotesiskan memiliki unit satuan yang berbeda-beda sehingga perlu dilakukan standardisasi untuk menjadikan semua unit satuan dari variabel yang akan hilang dan skala tiap variabel akan seragam. Analisis jalur dibuat untuk mempresentasikan hubungan kausal antarvariabel ke dalam bentuk gambar sehingga semakin mudah terbaca. Untuk mempermudah memahami istilah-istilah dalam analisis jalur, dapat digunakan contoh diagram jalur pada Gambar 1 .

Model diagram jalur adalah suatu diagram yang menghubungkan antara variabel bebas, perantara dan tergantung yang ditunjukkan dengan menggunakan anak panah. Diagram jalur adalah bentuk grafik dari keseluruhan hubungan yang ada dalam konstruksi model. Diagram jalur disusun berdasarkan pengetahuan secara umum (teoritis) dengan mempertimbangkan dasar hubungan kausal antarpeubah dan berdasarkan pertimbangan-pertimbangan dari penelitian sebelumnya atau berdasarkan perkiraan-perkiraan dasar untuk mempermudah analisis jalur. Variabel exogenous merupakan semua variabel yang dalam diagram tidak ada anak-anak panah yang menuju ke arahnya. Variabel ini berfungsi sebagai variabel bebas atau penyebab (Contoh: variabel $X_{1}$ dan $X_{2}$ terhadap $Y_{1}$ dalam sub struktur $I$, dan variabel $Y_{1}$ terhadap $\mathrm{Y}_{2}$ dalam sub struktur II). Variabel endogenous merupakan variabel yang mempunyai anak panah yang menuju ke arahnya (variabel $\mathrm{Y}_{1}$ untuk sub struktur I dan variabel $Y_{2}$ untuk sub struktur II). Variabel yang termasuk di dalamnya ialah mencakup semua variabel perantara dan tak bebas.

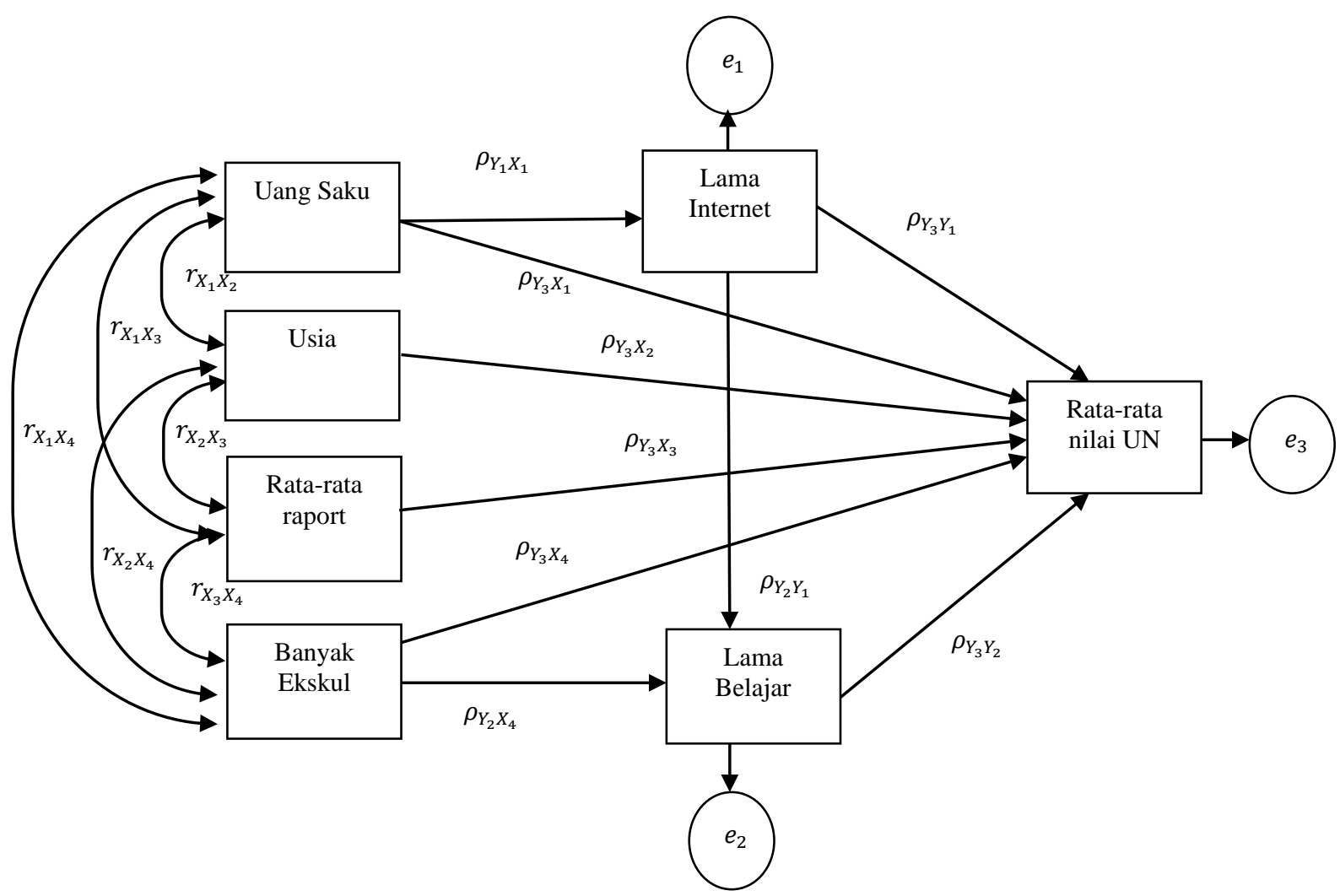

Gambar 1. . Diagram Jalur Pada Penelitian 
Koefisien jalur $(\rho)$ adalah koefisien regresi standar yang menunjukkan pengaruh langsung dari suatu variabel bebas terhadap variabel tergantung dalam suatu model jalur tertentu $\left(\rho_{Y_{1} X_{1}}\right.$ dan $\rho_{Y_{1} X_{2}}$ untuk sub struktur I serta $\rho_{Y_{2} X_{1}}, \rho_{Y_{2} X_{2}}$, dan $\rho_{Y_{2} Y_{1}}$ untuk sub struktur II). Direct Effect (DE) adalah pengaruh langsung yang dapat dilihat dari koefisien jalur dari variabel eksogen ke variabel endogen. Misalnya variabel $X_{1}$ dan $X_{2}$ terhadap $Y_{1}$, serta variabel $X_{1}, X_{2}$, dan $Y_{1}$ terhadap variabel $Y_{2}$.f. Indirect Effect (IE) adalah urutan jalur melalui satu atau lebih variabel perantara. Sebagai contoh pengaruh variabel $X_{1}$ terhadap $Y_{2}$ melalui variabel $Y_{1}$ dan pengaruh variabel $X_{2}$ terhadap $Y_{2}$ melalui variabel $Y_{1}$. Residue mencerminkan adanya varian yang tidak dapat diterangkan atau pengaruh dari semua variabel yang tidak terukur ditambah dengan kesalahan pengukuran ( $\mathrm{e}_{1}$ dan $\mathrm{e}_{2}$ pada Gambar 1 ) yang merefleksikan penyebab variabilitas yang tidak diketahui pada hasil analisis. Struktur model dasar dari analisis jalur adalah:

$$
\underset{p x 1}{\boldsymbol{Y}}=\underset{\text { pxp px1 }}{\boldsymbol{B}} \quad \boldsymbol{Y}+\underset{p x q q x 1}{\boldsymbol{\Gamma}} \boldsymbol{X}+\underset{p x 1}{\boldsymbol{e}}
$$

Model analisis jalur dibedakan menjadi 2 model(Lleras, 2005) yaitu model rekursif dan model nonrekursif. Model rekursif terbentuk apabila hubungan yang terjadi adalah hubungan satu arah (tidak dapat berbalik). Sedangkan model nonrekursif terbentuk apabila hubungan yang terjadi adalah hubungan dua arah atau dapat berbalik. berikut:

Asumsi analisis jalur adalah sebagai

1. Hubungan antarvariabel dalam model adalah linier, sebab akibat dan aditif. Linier maksudnya hubungan antarvariabel bersifat linier. Sebab akibat (kausal) yaitu menunjukkan adanya model sebab akibat dimana urutan kejadian akhirnya menuju pada variasi dalam variabel dependen (endogenous). Aditif maksudnya tidak terdapat efekefek interaksi.
2. Semua error tidak berhubungan atau berkorelasi dengan yang lain dalam model.

3. Hanya terdapat hubungan kausal satu arah dalam model.

4. Variabel diukur dengan menggunakan skala interval.

5. Variabel yang diamati diasumsikan diukur tanpa kesalahan.

6. Model yang digunakan diasumsikan atau dispesifikasikan secara tepat, yaitu dengan memasukkan semua penyebab ke dalam model

\section{Hasil dan Pembahasan}

Jenis data yang digunakan dalam penelitian ini adalah data primer yang diperoleh dari subjek penelitian dengan cara menyebarkan kuesioner terhadap siswa kelas XII yang sudah lulus Ujian Nasional. Adapun hubungan kausal antara variabel dapat dilihat pada gambar 2. Tahap awal pembentukan model adalah penelliti merencanakan model awal yang akan terbentuk dengan membuat diagram jalur. Terlebih dahulu dengan mengelompokkan variabel mana yang menjadi variabel endogen, dan variabel mana yang menjadi variabel eksogen.v Mencari nilai korelasi antarvariabel. Menghitung besar koefisien jalur dengan mengalikan invers matriks korelasi antarvariabel eksogen dengan matriks korelasi antara variabel eksogen dengan variabel endogen. Pengujian kesesuaian model dan koefisien jalur. Koefisien yang tidak signifikan secara statistik, dikeluarkan dari model. Pengujian asumsi analisis jalur. Jika memenuhi asumsi maka bisa dilanjutkan ke langkah berikutnya. Jika belum memenuhi asumsi maka harus dilakukan penanganan pelanggaran asumsi. Menentukan besar pengaruh tak langsung dan pengaruh total dari masing-masing variabel eksogen terhadap variabel endogen yang dipengaruhi dan melakukan interpretasi model akhir yang diperoleh.

Sebelum dilakukan perhitungan koefisien jalur, terlebih dahulu melakukan perancangan diagram jalur model awal. Perancangan diagram jalur model awal dibu- 
at berdasarkan pengetahuan secara umum (teoritis) dengan mempertimbangkan dasar hubungan kausal antarvariabel dan berdasarkan pertimbangan-pertimbangan penelitian sebelumnya atau berdasarkan perkiraan-perkiraan dasar. Berikut diagram jalur model awal yang dihasilkan dapat dilihat pada Gambar.2. Berdasarkan analisis dapat dilihat pengaruh hubungan antara masingmasing variabel yang digunakan dalam penelitian ini.

Berdasarkan Tabel 1 dapat dilihat besar pengaruh masing-masing variable. Lama internet pada penelitian ini memiliki maksud bahwa seberapa sering mengguna- kan internet (jam/hari). Selain itu responden yang diambil adalah merupakan pelajar dalam rumpuan sains dan juga sosial yang telah diambil berdasarkan teknik sampling secara acak (random). Pada tabel 2 juga dapat dilihat bahwa uang saku siswa memiliki hubungan pengaruh yang besar terhadap lama internet dan juga lama belajar siswa. Terdapat hubungan yang positif antara usia dengan rata-rata nilai ujian nasional, terdapat hubungan yang positif antara rata-rata nilai rapor dengan rata-rata nilai ujian nasional. Diagram model akhir dapat dilihat pada Gambar 3.

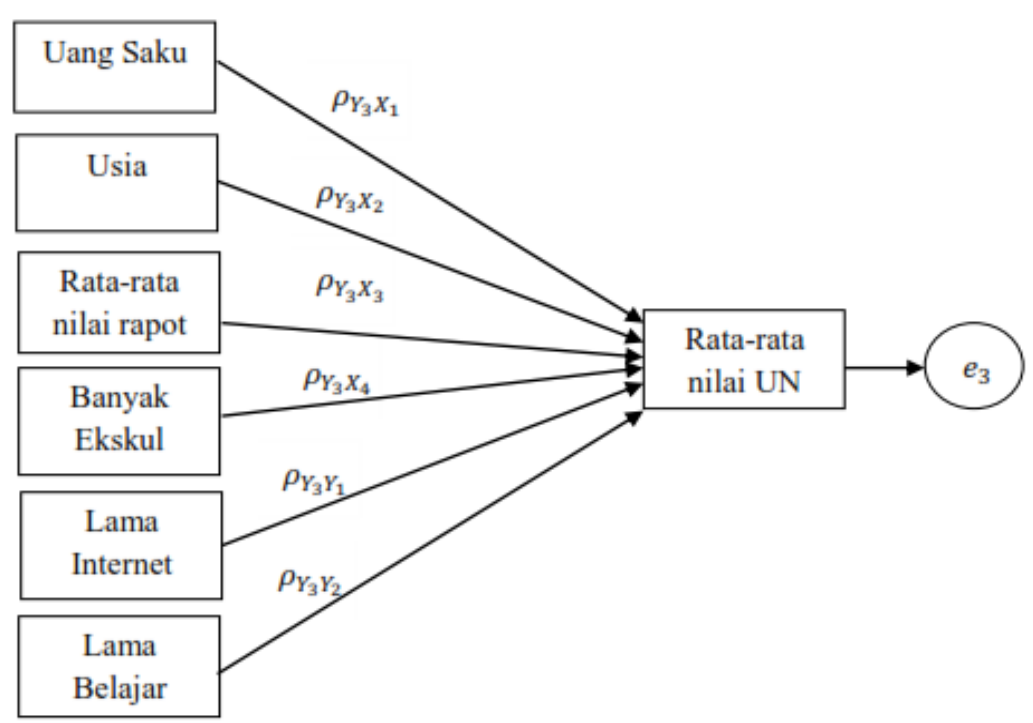

Gambar 2. Hubungan Kausal Instrumen Penelitian

Tabel 1. Besar Pengaruh setiap variable

\begin{tabular}{lccc}
\hline Arah Hubungan & $\begin{array}{c}\text { Pengaruh } \\
\text { Langsung }\end{array}$ & $\begin{array}{c}\text { Pengaruh Tak } \\
\text { Langsung }\end{array}$ & $\begin{array}{c}\text { Pengaruh } \\
\text { Total }\end{array}$ \\
\hline Uang Saku $\longrightarrow$ Lama Internet & 0,56 & 0 & 0,5 \\
Uang Saku $\longrightarrow$ Lama Belajar & 0 & 0,33 & 0,33 \\
Uang Saku $\longrightarrow$ Rata UN & 0 & $-0,41$ & $-0,41$ \\
Banyak Ekskul $\longrightarrow$ Lama Belajar & 0,09 & 0,20 & 0,29 \\
Lama Internet $\longrightarrow$ Lama Belajar & 0,10 & 0 & $-0,10$ \\
Usia $\longrightarrow$ Rata UN & 0,27 & 0 & 0,27 \\
Rata Rapor $\longrightarrow$ Rata UN & 0,56 & 0 & 0,56 \\
Banyak Ekskul $\longrightarrow$ Rata UN & $-0,18$ & $-0,20$ & $-0,38$ \\
Lama Internet $\longrightarrow$ Rata UN & $-0,27$ & 0.55 & 0,28 \\
Lama Belajar $\longrightarrow$ Rata UN & 0,24 & 0 & 0,24 \\
\hline
\end{tabular}




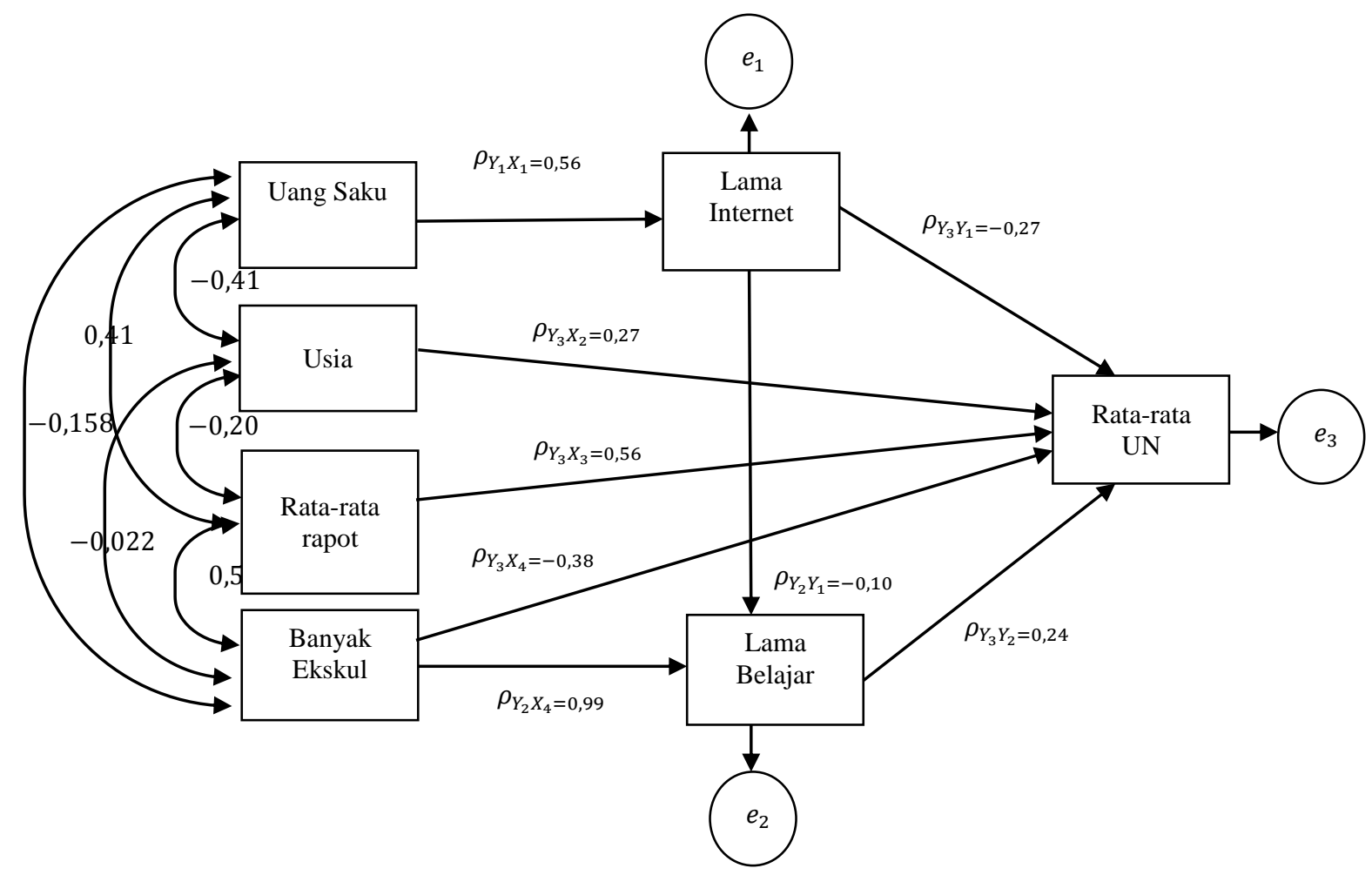

\section{Simpulan}

Berdasarkan analisis dapat disimpulkan bahwa secara statistika dapat diketahui besarnya dilai pengaruh antara variabel tersebut. Untuk meningkatkan nilai ratarata UN variable uang saku dan lama akses internet menjadi hal yang perlu diperhatikan oleh guru dan juga pihak lainnya yang terlibat pada pendidikan. Selain itu, siswa mendapatkan softskill dari ekstrakurikuler yang diselenggarakan oleh sekolah. Oleh karena itu penyediaan fasilitas dan pembimbing yang memadai harus diperhatikan

\section{Daftar Pustaka}

Atkinson, a C. (1986). Regression diagnostics. Encyclopedia of Statistical Sciences, 7, 689-694. https://doi.org/10.4135/97814129856 04

Bates, D. M., \& Watts, D. G. (1988). Review of linear regression. Nonlinear Regression Analysis and Its Applications, 1-31.

https:// doi.org/10.1002/97804703167 57.ch1
Caraka, R. E., \& Sugiarto. (2017).

Pemodelan penggunaan dana BOS terhadap rata-rata nilai rapot. In M. A. Dr. Nurul Imam, Dr. Bambang Hermanto, Dr. Syarifan Nurjan (Ed.), Semangat Publikasi Dalam Membangun Peradaban Negeri (pp. 144-164). Penerbit Wade.

Conover, W. J. (1971). Practical nonparametric statistics. The Statistician. https:/ / doi.org/10.2307/2986830

Depdiknas. Undang-Undang Nomor 20 Tahun 2003 tentang Sistem Pendidikan Nasional (2003). Jakarta.

Diputra, S., \& Indra, G. (2010). Analisi pengaruh dana bantuan operasional sekolah (BOS), rata-rata masa kerja guru, dan rasio siswa tidak mampu terhadap prestasi belajar siswa sekolah dasar negeri di Kota Denpasar. E-Jurnal Ekonomi Dan Bisnis Universitas Udayana, 2(1).

Furno, M. (2005). The Glejser test and the median regression. Sankhya: The Indian Journal of Statistics, 67(2), 335-358. 
Hakam, M. (2015). Analisis jalur terhadap faktor-faktor yang mempengaruhi indeks prestasi kumulatif (IPK) mahasiswa statistika UNDIP. Skripsi. Universitas Diponegoro Semarang.

Land, K. C. (1969). Principles of path analysis. Sociological Methodology,
1(1969), 3-37.

https:// doi.org/10.2307/270879

Lleras, C. (2005). Path analysis. Encyclopedia of Social Measurement.

https:// doi.org/http:/ /dx.doi.org/10 .1016/ B0-12-369398-5/00483-7 